\title{
The potential use of plant species within a Renosterveld landscape for the phytoremediation of glyphosate and fertiliser
}

\author{
DM Jacklin', IC Brink² and J de Waal' \\ 'Department of Geography and Environmental Studies, Stellenbosch University, Private Bag X1, Matieland 7602, South Africa \\ ${ }^{2}$ Department of Water and Environmental Engineering, Stellenbosch University, Private Bag X1, Matieland 7602, South Africa
}

In South Africa, fertiliser and herbicide pollutants resulting from agricultural practices indirectly lead to the degradation of surface freshwater and groundwater quality. Nitrogen and phosphorus, and glyphosate, derived from agricultural fertiliser and herbicide applications, respectively, contribute to watercourse toxicity. Adjacent to many of the surface freshwater systems are some of South Africa's most productive agricultural lands, where natural ecosystems are converted to croplands, resulting in the degradation of natural vegetation and deterioration of freshwater quality. The critically endangered status of some Renosterveld vegetation types is the product of agricultural expansion, nutrient loading through fertilisation and the spraying of herbicides. A buffer of Renosterveld vegetation along river corridors may contribute to the remediation of agricultural pollutants prior to entering watercourses. The utilisation of wetland plants occurring within Renosterveld for agricultural pollutant extraction can increase river corridor biodiversity, creating indigenous refuges and facilitating habitat connectivity. A laboratory phytoremediation system was designed and constructed to investigate the pollutant-removal potential of indigenous species occurring in Renosterveld vegetation (amongst other areas), compared with commonly used invasive alien plants (IAP) in floating wetland designs. Five pollutant parameters - ammonia, nitrate, orthophosphate and two glyphosate concentrations - reflect environmental stresses on 14 wetland species naturally occurring within Renosterveld vegetation. Effluent analyses indicated significant removal efficiencies for the indigenous vegetation across both fertiliser and herbicide pollutants, with the two most effective species identified as Phragmites australis and Cyperus textilis, with $95.87 \%$ and $96.42 \%$ removal, respectively. All wetland species displayed greater pollutant removal than the unvegetated soil control and when compared to an IAP and palmiet assemblage, indicated similar pollutant-removal efficiencies, justifying their use as an acceptable alternative.
CORRESPONDENCE

J de Waal

EMAIL

janniedw@sun.ac.za

\section{DATES}

Received: 29 October 2018

Accepted: 3 December 2019

\section{KEYWORDS}

phytoremediation

water quality

bioremediation

\section{COPYRIGHT}

() The Author(s)

Published under a Creative

Commons Attribution 4.0

International Licence

(CC BY 4.0)

\section{INTRODUCTION}

In the Western Cape, South Africa, increased agricultural development is responsible for the degradation of critically endangered natural Renosterveld vegetation and the deterioration of freshwater quality (Von Hase et al., 2003; Curtis, 2013). Non-point source pollution of ground and surface waters by fertilisers and pesticides within agricultural regions includes both nonirrigated and irrigated crop fields (Barcelo, 1997; Budd et al., 2009). Here the primary cause of water quality impairment is nutrient enrichment (King et al., 2012) where excess fertiliser nutrients, phosphorus $(\mathrm{P})$ and nitrogen $(\mathrm{N})$ contribute greatly to surface water eutrophication and water quality degradation (Lee et al., 1978; Schoumans et al., 2014; Redfield, 1958). The treatments applied to various agricultural crops lead to the degradation of freshwater (Zalidis et al., 2002) and groundwater (Arumi et al., 2005; Lam et al., 2010).

Typically, herbicides are introduced into the environment with the intention of applying effects on specific target organisms (Pilon-Smits, 2005; Chèvre et al., 2006). Unfortunately, the toxic action is not only exerted on the area where it is applied, but, through overhead spray, leaching and soil erosion transport, a substantial amount of the herbicide and its degradatory products reach freshwater aquatic ecosystems (Beach and Carlson, 1993; Barcelo, 1997; Kanwar et al., 1997; Dabrowski, 2001; Chèvre et al., 2006). The effect is most acute where agricultural practices border surface waters (Pérez et al., 2011; Mensah et al., 2013; Tran et al., 2017).

The nutrient status of the 20 largest freshwater river catchments in South Africa, based on dissolved inorganic nitrogen $\left(\mathrm{NO}_{3}^{-}+\mathrm{NO}_{2}^{-}\right)$and dissolved phosphorus $\left(\mathrm{PO}_{4}^{3-}\right)$, indicate that the nutrient levels within most watercourses exceed the recommended water quality guidelines for plant life (De Villiers and Thiart, 2007). This trend repeats in all but six of South Africa's largest river catchments, where $\mathrm{PO}_{4}^{3-}$ levels further exceed the recommended concentration for aquatic animal life in an alarming 60\% of the rivers (Von Hase et al., 2003; De Villiers and Thiart, 2007; Curtis, 2013). Nutrient proliferation poses a serious and costly environmental conservation threat to water quality and biodiversity. The negative environmental effects of eutrophication further reduce biodiversity and functioning of aquatic ecosystems and deteriorate surface water quality (Schoumans et al., 2014).

Some of the country's most productive farmlands are located adjacent to watercourses, transforming the surrounding ecosystems in favour of the crops produced (Giliomee, 2006). Renosterveld lowlands vegetation, within the Cape Floristic Region (CFR) of the Western Cape, South Africa, comprises some of the most transformed and under-conserved areas within the CFR (Kemper et al., 1999; Rouget et al., 2003). The severity of Renosterveld transformation indicates that more 
than $95 \%$ of natural vegetation has been lost to agricultural development (McDowell and Moll, 1992; Curtis, 2013).

Phytoremediation is the use of vegetation for the in-situ treatment of contaminated soils, sediments and water, applicable to sites that contain organic, nutrient or metal pollution (Schnoor et al. 1995; Hughes et al., 1997; Dietz and Schnoor, 2001). The technology is appropriate for any scenario where the pollutants are sequestered, degraded, immobilized or metabolized by the plant roots through rhizosphere processes (Anderson et al., 1993; Terry and Banuelos, 2000; Dietz and Schnoor, 2001).

The identification of indigenous wetland species occurring within Renosterveld that are capable of phytoremediating agricultural contaminants assists species-specific inclusion of indigenous plants into vegetated buffer strips adjacent to waterways. Vegetative buffers potentially connect the remaining Renosterveld fragments, combating biodiversity loss and subsequently, through rhizosphere processes, improving the quality of agricultural runoff from hillslopes prior to deposition into the freshwater systems (Kemper et al., 1999). Due to the high cost attributed to water treatment, developing countries do not generally have the financial capacity and expertise to implement advanced water treatment systems (Mara, 2004; Henze, 2008), whereas plant cultivation and harvesting are relatively inexpensive processes compared to advanced wastewater treatment systems, making phytoremediation an attractive alternative for the chemical and biological treatment of freshwater aquatic ecosystems (Sekabiera et al., 2011). A buffer of Renosterveld vegetation may consequently be an appropriate solution when agricultural pollutant removal is required (Von Hase et al., 2003). The need to mitigate environmental degeneration necessitates proactive biodiversity conservation strategies, with the aim of ameliorating the freshwater aquatic ecosystems.

The purpose of this study was to investigate the phytoremediation capabilities of plant species found in (though not limited to) the critically endangered Renosterveld vegetation type, enabling a comparison with unvegetated soil and invasive plant species currently utilized in sustainable urban drainage systems and constructed wetlands.

\section{METHODS AND MATERIALS}

\section{Field reference}

The Breede River originates in the mountains of the Ceres basin, in the Western Cape Province of South Africa $\left(34^{\circ} 23^{\prime} 53.51^{\prime \prime} \mathrm{S}\right.$, $20^{\circ} 50^{\prime} 27.87^{\prime \prime} \mathrm{E}$ ) (Curtis, 2013). Although many Renosterveld vegetation types exist in the Western Cape, this study focused only on Ruens Silcrete Renosterveld, occurring along the Breede River in the Overberg region (Fig. 1). Although all Renosterveld types are under threat, Rûens Silcrete Renosterveld was selected on account of its alarming rate of deterioration, conservation status, adjacency to the watercourse and position as a riparian buffer. Riparian buffers can reduce the risk of surface water contamination via surface runoff and pollutant leaching, limiting the transport of agricultural contaminants into natural waterways (Beltrano et al., 2013; Gomes et al., 2016; Lowrance et al., 1985).

Water-quality degradation, as a result of agricultural fertiliser and herbicide applications mainly for the farming of canola (Brassica napus), is accompanied by an alarming rate of irreversible conversion of the natural Renosterveld vegetation to croplands, with pollutants exerting pressure on the natural veld and waterways.

\section{Laboratory experiment}

In investigating the pollutant removal performance of indigenous plant species, a laboratory experiment was conducted between April 2017 and May 2018. The design of an indoor system (Fig. 2), prevented precipitation from altering the quantity and quality of the influent water-pollutant solution, whilst maintaining ambient solar radiation and temperature.

The experiment included 14 indigenous plant species of varying morphology naturally occurring within Renosterveld, an unvegetated soil control, and three IAP species and palmiet for community comparison.

\section{Plant selection for phytoremediation}

Various phytotechnologies utilize different plant properties from a range of plant species for each pollutant extraction scenario (Read et al., 2008). Established plant properties for advantageous

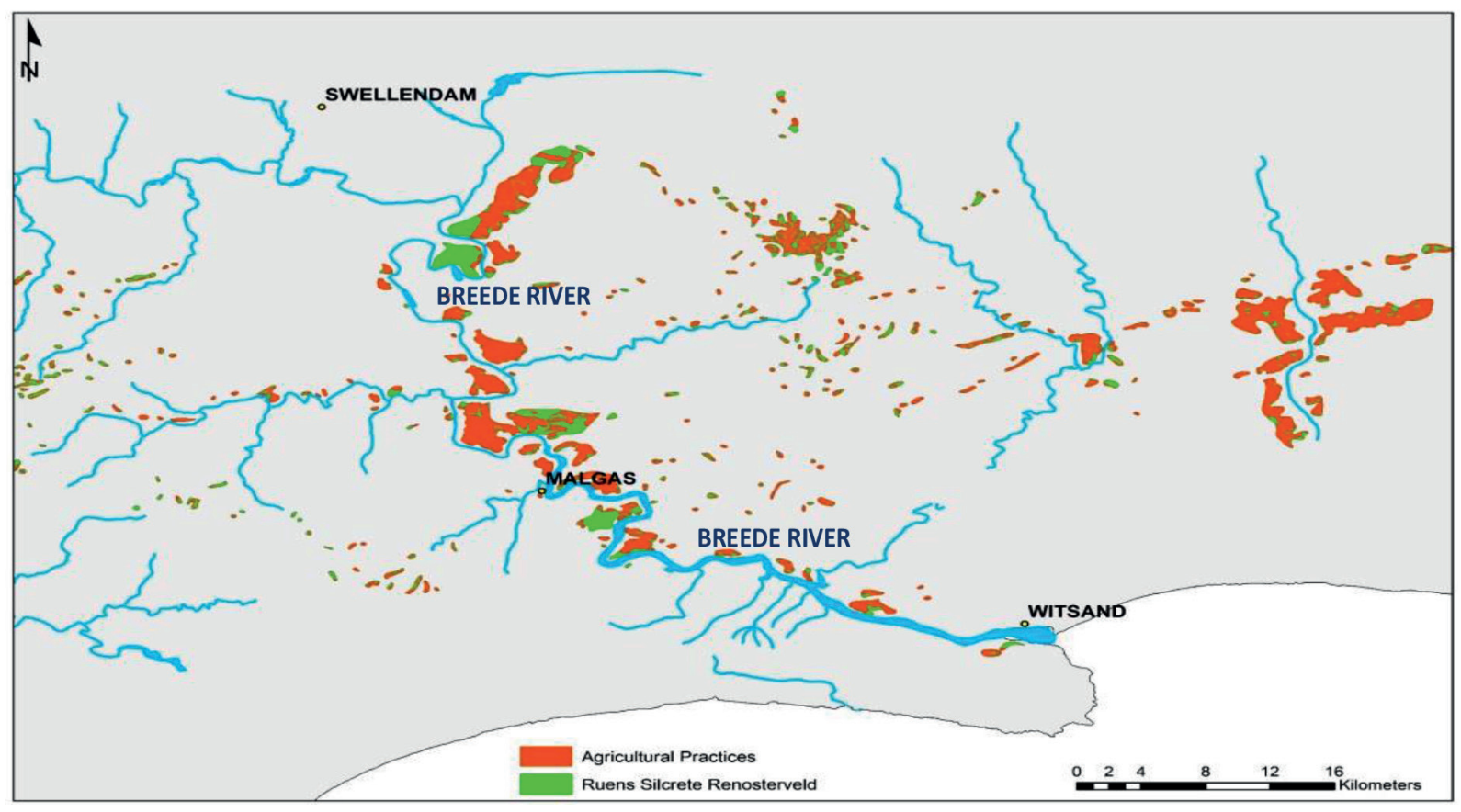

Figure 1. Agricultural dominance on Rûens Silcrete Renosterveld - Breede River, Western Cape (data source: SANBI, 2003) 
phytoremediation are: fast growing, high biomass, competitive, hardy and tolerant to contaminants (Pilon-Smits, 2005; Read et al., 2010). In addition, plant species were selected to represent different growth habits (grasses, shrubs and reeds) appropriate in various environmental conditions, but considered species that typically thrive in river corridors. Selection of plant species was based on morphology (influencing physiology), conservation status, visual aesthetics, availability, invasive properties, and potential to tolerate increased moisture and conditions of drought, deduced from habitat distribution. The selected plants (Table 1) consist of species that require varying moisture content. The species variations enable the potential establishment of a community along a riverbank slope, with species planted at different distances from the watercourse. This variability increases community tolerance during seasonal fluctuations, where intermittent conditions of drought and saturation exist. The species selected represent genera that were capable of rapidly maturing during the experimental timeframe, providing an accurate representation of each species' capacity for nutrient removal.

All selected plant species are indigenous to South Africa and can be found in Renosterveld ecoregions, among others. Three plant species classified as alien invasive and one additional aggressive indigenous species (Prionium serratum) were selected to represent an IAP and palmiet community. The IAP species were selected for their current use in constructed wetlands, wastewater treatment facilities, SuDS and biofiltration treatment trains. These species (Table 2) have proven excellent remediators of polluted water, and are commonly used internationally (Schachtschneider et al., 2010; Milandri et al., 2012).

Prionium serratum is listed with the IAPs with regard to its proliferation and growth properties within a sensitive ecosystem, and its lack of distribution in the section of the Breede River, exposed to agricultural pollutants, under study. Although listed with the IAPs, it is of this author's opinion that Prionium serratum does not present invasive properties to the freshwater systems of the Western Cape. The ecosystem services of palmiet may be invaluable in the sustainability of aquatic systems. The authors acknowledge that more research has to be conducted to establish the exact role of this plant species.

\section{Experimental design}

In evaluating the remediation capabilities of individual species, a total of 90 containers were constructed from $110 \mathrm{~mm}$ diameter $\times 500 \mathrm{~mm}$ length polyvinyl chloride (PVC) piping, each with a $40 \mathrm{~mm}$ diameter $\times 180 \mathrm{~mm}$ length threaded slit drainage pipe that protruded from the sealed base of each silo, enabling effluent collection into sampling containers directly below. The base of each silo was sealed with a $150 \mathrm{~mm} \times 150 \mathrm{~mm}$ square PVC sheet, perpendicular to the length of the silo. A mould was created,

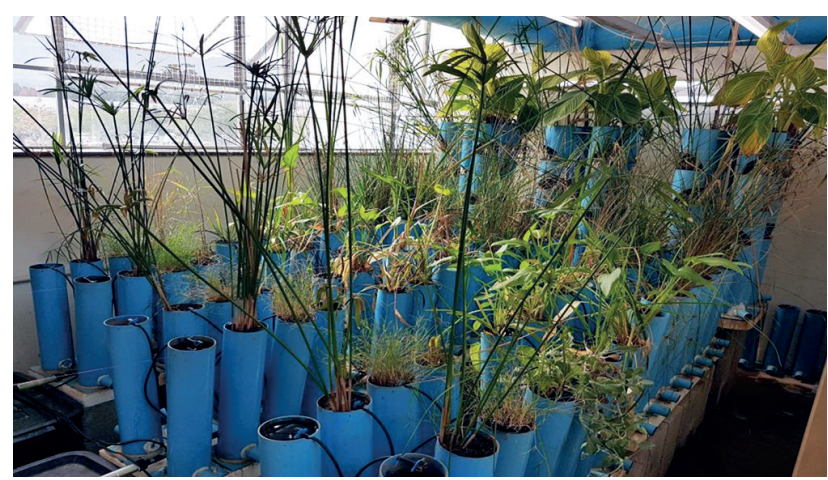

Figure 2. Experimental layout of the constructed laboratory phytoremediation system adding support to the effluent drainage pipe, by tailoring a cube of isoboard into a shape inserted below the drainage pipe. The mould assists effluent removal by steering the filtered effluent water solution into the drainage pipe to allow for discharge.

For the combined species remediation analyses and comparison with IAP and palmiet species, a total of 15 silos were constructed from $160 \mathrm{~mm}$ diameter $\times 1075 \mathrm{~mm}$ length $\mathrm{PVC}$ piping, each with a $40 \mathrm{~mm}$ diameter $\times 250 \mathrm{~mm}$ length threaded slit drainage pipe protruding from the sealed base of each silo, enabling effluent collection into sampling containers directly below. As with the design for individual species remediation silos, a mould was created to support effluent drainage. Four silos were used per treatment with four different species per silo: two species prevailing in dry and two in wet conditions. For each treatment investigating phytoremediation performance, two silos of indigenous species and two silos of alien invasive species with palmiet were used. Voids were cut along the length of the silos to enable plant establishment at different intervals of the silo; at each void a plant species was introduced (the quantity per species depended on the surface cover of each species, quantity of grass $>$ quantity of sedges). A consistent volume of growth medium per plant ensured that the effect of soil degradation was taken into account. Soil media may play a significant role in pollutant remediation, thus unvegetated controls were included to establish the role of soil in pollutant remediation through degradation and adsorption. Drainage layers were added below the soil growth medium comprising of coarse sand and gravel; the layers covered the drainage pipes. The drainage layers prevented sedimentation within the slits of the drainage pipe, preventing clogging of the effluent runoff.

\section{Experimental procedure}

All plant species were planted in September 2017 and received municipal tap water irrigation for 6 months, allowing plants to mature and adjust to new growing conditions. Thereafter, the plants received standardized water-pollutant treatments (Table 3). During the transplantation process, special care was taken to remove all visible foreign organic matter and soil. This limited the contribution of external factors to

Table 1. Indigenous plant species found in Renosterveld

\begin{tabular}{lc}
\hline Species & Common name \\
\hline Cynodon dactylon & Scutch grass \\
Cyperus textilis & Mat sedge \\
Phragmites australis & Fluitjiesriet \\
Typha capensis & Bulrush \\
Juncus effuses & Common rush \\
Carpobrotus edulis & Sour fig \\
Arctotis acaulis & Renoster marigold \\
Zantedeschia aethiopica & Arum lily \\
Aristea capitate & Blue sceptre \\
Juncus lomatophyllus & Leafy juncus \\
Bolboschoenus maritimus & Alkali bulrush \\
Isolepsis prolifera & Vleigras \\
Juncus kraussii & Dune slack rush \\
Eleocharis limosa & Schrad \\
\hline
\end{tabular}

Table 2. Invasive alien plant species selected for their current use in wastewater treatment

\begin{tabular}{lc}
\hline Species & Common name \\
\hline Pennisetum clandestinum & Kikuyu \\
Arundo donax & Giant reed \\
Canna indica & Canna \\
Prionium serratum & Palmiet \\
\hline
\end{tabular}


the phytoremediation process, ensuring equal conditions throughout the system. The plant roots were handled with extreme care so as not to damage them in any way. If trimming of the stems was deemed necessary, it was done in a manner that would not harm plant development.

The soil used as growth medium was collected from the Overberg region $\left(34^{\circ} 20^{\prime} 15.82^{\prime \prime} \mathrm{S}, 20^{\circ} 20^{\prime} 33.85^{\prime \prime} \mathrm{E}\right)$, to reflect natural conditions for plant root growth and pollutant adsorption. This familiarity further alleviated stresses during plant extraction and transplantation, establishing ideal growing conditions. Dry and wet sieve analyses classified the soil, by implementing the USDA classification system (Buol et al., 2011) as Sandy Loam. This texture allowed the diffusion of water through the medium, establishing remediation potential.

An automated irrigation system was installed and fitted with three submersible pumps, one for each treatment, submersed within their respective water storage tanks. Different drippers were used for the different silo sizes, $870 \mathrm{~mL} / \mathrm{h}$ and $2070 \mathrm{~mL} / \mathrm{h}$ for the individual species per silo and multiple species per silo, respectively. The system guaranteed a consistent irrigation regime, with frequency set for irrigation every $72 \mathrm{~h}$, based on the saturation rate and permeability of the growth silos. A dosage of $0.653 \mathrm{~L} / 3$-days and $1.533 \mathrm{~L} / 3$-days was regarded as the optimum irrigation rate for the individual species per silo and multiple species silos, respectively.

\section{Fertiliser selection}

The selected nutrient ( $\mathrm{N}$ and $\mathrm{P}$ ) concentrations, representative of fertiliser products regularly applied in the farming of canola, were selected to resemble real-world nutrient pollution. The recommended fertiliser application for canola, compiled by the Department of Agriculture, Forestry and Fisheries (DAFF), was used in calculating the concentration of the compounds needed to reflect environmental conditions (DAFF, 2016).

\section{Herbicide selection}

A glyphosate-based herbicide was selected for this study as the product is widely used by the agricultural sector in the Overberg. Two glyphosate dosage strengths were selected to represent a non-toxic contamination and a worst-case scenario humanerror contamination. The non-toxic glyphosate threshold concentration is the maximum concentration at which aquatic ecosystem degradation does not occur (You et al., 2003). The worst-case scenario dosage was selected with discovery that farmers commonly apply herbicide at extreme concentrations, either through application error or lack of product dosage understanding (De Kock, 2017).

The plants received treatment for a continuous 50-day period at treatment dosages (Table 3) irrigated 20 days prior to the first round of sampling. This period was deemed sufficient to allow for the transport of excess non-polluted tap water that may have lingered within the silos, out of the system, ensuring negligible pollutant dilution.

\section{Sampling process and analyses}

Samples were collected on 5 occasions $(n=4)$ during the study. The first round of sampling was initiated on 3 March 2018, examining the baseline nutrient concentrations prior to influent treatment; this determined the nutrient concentrations within each growth silo before the addition of pollutants. The baseline determination allowed for precise comparison between influent and effluent water, by taking the pre-treated conditions within the silos into account. The second round of sampling occurred 20 days post initial treatment. Thereafter sampling was
Table 3. Influent pollutant treatment concentrations

\begin{tabular}{lcc}
\hline Pollutant & Parameter & Concentration $(\mathrm{mg} / \mathrm{L})$ \\
\hline \multirow{2}{*}{ Fertiliser } & Ammonia-N & 37.096 \\
& Nitrate-N & 9.274 \\
& Orthophosphate-P & 17.39 \\
\hline \multirow{2}{*}{ Herbicide } & Glyphosate & 225 \\
& & 0.7 \\
\hline
\end{tabular}

undertaken every 10 days. Investigating the percentage removal of all plants was possible as influent concentrations were premixed to standardised levels and baseline concentrations were known. Effluent was collected by collection containers directly below the drainage pipes of each silo; water storage samples were also collected from each influent storage tank. Treatment was received by two plants per species, establishing experimental duplication and reducing outlier influence. The effluent solutions were collected in $90 \mathrm{~mL}$ specimen containers.

In order to evaluate the experiment's pollutant removal performance, various water quality parameters were measured throughout the experiment. These included $\mathrm{pH}$, dissolved oxygen (DO), electrical conductivity (EC), ammonia $\left(\mathrm{NH}_{3}\right)$, nitrate $\left(\mathrm{NO}_{3}^{-}\right)$, orthophosphate/soluble reactive phosphorus $\left(\mathrm{PO}_{4}^{3-} / \mathrm{SRP}\right)$ and glyphosate $\left(\mathrm{C}_{3} \mathrm{H}_{8} \mathrm{NO}_{5} \mathrm{P}\right)$. The $\mathrm{mg} / \mathrm{L} \mathrm{NH} \mathrm{NH}_{3}-\mathrm{N}$, $\mathrm{mg} / \mathrm{L} \quad \mathrm{NO}_{3}-\mathrm{N}$ and $\mathrm{mg} / \mathrm{L} \quad \mathrm{PO}_{4}-\mathrm{P}$ were measured to ascertain the $\mathrm{N}$ and $\mathrm{P}$ content within the effluent solution. The $\mathrm{pH}, \mathrm{DO}$ and EC were measured using the HQ440d Benchtop MultiParameter Meter manufactured by Hach. The device is a handheld water quality meter, using parameter-specific probes to instantaneously measure various water-quality parameters. The IntelliCAL PHC281 probe was used to measure the $\mathrm{pH}$, whereas the IntelliCAL LDO101 probe measured the DO concentration and the IntelliCAL CDC401 probe measured the in-situ EC concentrations. The effluent samples were filtered with a $0.45 \mu \mathrm{m}$ syringe filter prior to nutrient analyses. The $\mathrm{NH}_{3}-\mathrm{N}, \mathrm{NO}_{3}-\mathrm{N}$ and SRP concentrations were measured colorimetrically using the Hach DR3900 Benchtop Spectrophotometer and the TNTplus 832, TNTplus 835 and TNTplus 845 test kits, respectively. The method for glyphosate effluent sample collection was identical to the collection procedure of the fertiliser nutrients. Waters Acuity Ultra-Performance Liquid Chromatography (UPLC) was coupled to a Xevo Triple Quadrupole Tandem Mass Spectrometer (MS/MS) and used for high-resolution UPLC-MS/MS analysis. Glyphosate per sample was further separated by multiple reaction monitoring (MRM) using electrospray ionisation in a positive mode. The samples were collected and analysed by the Central Analytical Facility: LCMS division at Stellenbosch University.

\section{Evaluating pollutant removal}

In evaluating pollutant removal efficiency, the baseline concentration values needed to be known. The measured baseline concentration for each silo was deducted from the measured effluent concentration to allow for percentage removal calculations for each sampling round (Eq. 1).

$$
\frac{\text { Influent conc. }-(\text { Effluent conc. }- \text { Baseline conc. })}{\text { Influent conc. }} \times \frac{100}{1}
$$

where

Influent conc. = Influent concentration $(\mathrm{mg} / \mathrm{L})$

Effluent conc. = Effluent concentration $(\mathrm{mg} / \mathrm{L})$

Baseline conc. $=$ Baseline concentration $(\mathrm{mg} / \mathrm{L})$

The Kruskal-Wallis $H$-test, non-parametric ANOVA, was used for the evaluation of the wetland community versus unvegetated soil; thereafter a Student's $t$-test was used in analysing the individual wetland species' pollutant removal and the indigenous 
Renosterveld assemblage versus IAP assemblage. The ranking of the indigenous wetland species found in Renosterveld community with regard to species pollutant remediation across all pollutants required a one-way ANOVA, with a normal Kruskal-Wallis $H$-test performed. Statistical analyses were executed in Python by means of the data analytical library.

\section{RESULTS AND DISCUSSION}

\section{Pollutant remediation efficacy of indigenous vegetation versus unvegetated soil}

In analysing the pollutant retention performance, the indigenous vegetation (excluding palmiet) performed better in the removal of nutrient pollutants and the $225 \mathrm{mg} / \mathrm{L}$ glyphosate pollutants than the unvegetated soil control. The non-parametric ANOVA, comparing the percentage pollutant removal of indigenous wetland plant species and unvegetated soil, indicated that the removal efficiencies of the two treatment biofilters were statistically different (Table 4).

There is a significant difference ( $p \leq 0.05)$ between the vegetation and unvegetated soil control for nutrient pollutants and $225 \mathrm{mg} / \mathrm{L}$ glyphosate pollutants over 4 rounds of sampling. Therefore, the removal of pollutants by wetland species found in Renosterveld vegetation was significantly more effective than by the unvegetated soil control.

Table 5 illustrates that over time, on average, the vegetated medium was consistently more effective in the removal of agricultural pollutants than unvegetated soil, although both displayed substantial herbicide removal (>80\%). Bacterial establishment in unvegetated soil did not considerably improve the remediation of nutrients. The greatest removal performance was found in the presence of vegetation, with rhizosphere root bacteria and micro-organisms as possible contributors.

\section{Individual pollutant removal performance of indigenous wetland species}

The objective of this test was to identify the pollutant removal performance of individual wetland species found within Renosterveld over time. Plant species display unique remediation capabilities, with affinity to different pollutants. The 14 wetland plants reduced nutrient concentrations of the effluent over the duration of the study, with removal averaging $86 \%, 87 \%$ and $88 \%$ for $\mathrm{NH}_{3}-\mathrm{N}, \mathrm{NO}_{3}-\mathrm{N}$ and SRP, respectively (Fig. 3).

Figure 3 illustrates that the wetland plant species found in Renosterveld displayed greater nutrient removal efficiencies than the unvegetated soil control through time. The nutrient removal values of all indigenous species displayed significant removal efficiencies compared to the unvegetated soil, as depicted in Table 6, with the exception of 2 species; Carpobrotus edulis and Arctotis acaulis, both displaying mean percentage nutrient removal values of $68 \%$.

\section{Ammonia (mg/L N)}

All plant species were effective in removing $\mathrm{NH}_{3}-\mathrm{N}$ with effluent concentrations being reduced by $70-97 \%$ (average removal $86 \%$ ), whilst the unvegetated soil control removed an average of $65 \%$.

\section{Nitrate $(\mathrm{mg} / \mathrm{L} \mathrm{N})$}

As with $\mathrm{NH}_{3}$, all the plant species were effective in removing $\mathrm{NO}_{3}-\mathrm{N}$ from the influent solution. The removal efficiency ranged between 65 and 96\% (average removal 87\%), whilst the soil control removed $59 \%$, on average. In contrast to the findings of previous research (Bratieres et al., 2008; Read et al., 2008; Milandri et al., 2012), this study showed far greater $\mathrm{NO}_{3}-\mathrm{N}$ removal. These contrasting
Table 4. Comparison (Kruskal-Wallis $\mathrm{H}$-test) of removal performance of vegetation versus unvegetated soil

\begin{tabular}{lcccc}
\hline Pollutant & $\mathrm{NH}_{3}-\mathrm{N}$ & $\mathrm{NO}_{3}{ }^{-\mathrm{N}}$ & $\mathrm{PO}_{4}{ }^{3-}-\mathrm{P}$ & $\begin{array}{c}225 \mathrm{mg} / \mathrm{L} \\
\text { glyphosate }\end{array}$ \\
\hline$p$-value & 0.00152 & 0.00304 & 0.00227 & 0.01775 \\
\hline
\end{tabular}

$\mathrm{n}=4, d f=3$

Table 5. Average removal of agricultural pollutants for the duration of the experiment

\begin{tabular}{lcc}
\hline \multirow{2}{*}{ Pollutant } & \multicolumn{2}{c}{ Mean pollutant removal with time (\%) } \\
\cline { 2 - 3 } & $\begin{array}{c}\text { Indigenous } \\
\text { Renosterveld species }\end{array}$ & Soil control \\
\hline Ammonia $\left(\mathrm{NH}_{3}-\mathrm{N}\right)$ & 86 & 65 \\
Nitrate $\left(\mathrm{NO}_{3}^{-}-\mathrm{N}\right)$ & 87 & 59 \\
Soluble reactive & 88 & 61 \\
phosphorus $\left(\mathrm{SRP} / \mathrm{PO}_{4}{ }^{3-}-\mathrm{P}\right)$ & 96 & 92 \\
$0.7 \mathrm{mg} / \mathrm{L}$ glyphosate & 97 & 83 \\
$225 \mathrm{mg} / \mathrm{L}$ glyphosate & & \\
\hline
\end{tabular}

findings may be the result of the specific plant species under study, micro-organisms, the establishment of bacterial assemblages in the rhizosphere, and the drip irrigation applied as opposed to rapid high volume irrigation (Bratieres et al., 2008; Read et al., 2008). The irrigation system implemented in this experiment percolated influent dosage through the silos at a slower rate compared to previous work, allowing more time for the uptake of water and dissolved nutrients.

\section{Soluble reactive phosphorus (SRP or $\mathrm{mg} / \mathrm{L} P$ )}

Following effective remediation all the plant species displayed a strong removal efficiency for SRP, with percentage SRP removed ranging from 66-99\% (average SRP removal 88\%), whilst the soil control removed on average of $61 \%$. The three most effective wetland species for nutrient pollutant remediation were consistent across all nutrients, with Cynodon dactylon, Phragmites australis and Cyperus textilis all present. Exposed to $\mathrm{NH}_{3}$ pollution, plant species were, on average, $31 \%$ more effective than unvegetated soil and $36 \%$ more effective for both $\mathrm{NO}_{3}{ }^{-}$and SRP. All 14 indigenous plant species found in Renosterveld effectively remediated herbicide pollution over both glyphosate concentrations $(0.7 \mathrm{mg} / \mathrm{L}$ and $225 \mathrm{mg} / \mathrm{L})$. The average removal efficiency of both herbicide concentrations is displayed in Fig. 4.

\section{Glyphosate (0.7 mg/L)}

The percentage removal by plant species for the $0.7 \mathrm{mg} / \mathrm{L}$ glyphosate influent was reduced by $92.84-99.39 \%$ (average vegetative removal 96.81\%), while the unvegetated soil control removed, on average, $92.21 \%$. The three most effective species: Juncus kraussii, Isolepsis prolifera and Cynodon dactylon, were, on average, $6.97 \%$ more effective than the unvegetated soil control.

\section{Glyphosate (225 mg/L)}

Similar to the removal efficiency of the less concentrated glyphosate solution, the percentage removal by vegetation for the $225 \mathrm{mg} / \mathrm{L}$ glyphosate influent ranged from 88.34-99.86\% (average vegetative removal $96.21 \%$ ), with the soil control on average removing $82.93 \%$. The three most effective species: Bolboschoenus maritimus, Aristea capitata and Typha capensis, were, on average, $16.67 \%$ more effective than the unvegetated soil control.

A $t$-test further compared the pollutant removal performance between individual wetland plant species and the unvegetated soil control, for all nutrient pollutants $\left(\mathrm{NH}_{3}, \mathrm{NO}_{3}{ }^{-}\right.$and SRP) and the $225 \mathrm{mg} / \mathrm{L}$ glyphosate-based herbicide. The $0.7 \mathrm{mg} / \mathrm{L}$ 


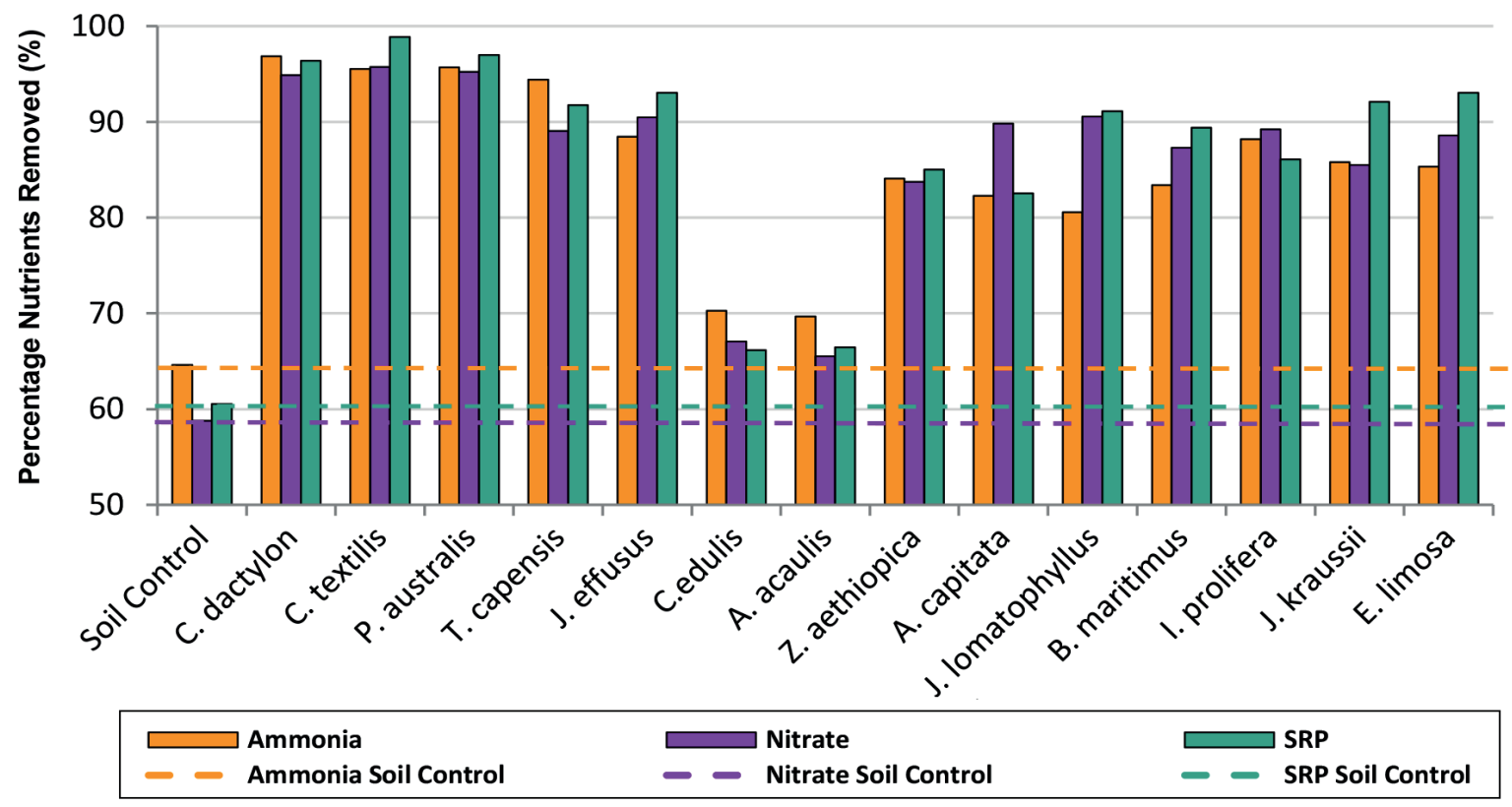

Figure 3. Average nutrient removal of plant species and soil over 4 rounds of sampling

Table 6. Comparison (t-test) of pollutant removal performance between plant species and unvegetated soil

\begin{tabular}{|c|c|c|c|}
\hline Species & $p$-value & Species & $p$-value \\
\hline $\mathrm{NH}_{3}-\mathrm{N}$ & & $\mathrm{NO}_{3}^{-}-\mathrm{N}$ & \\
\hline Cynodon dactylon & 0.000000232 & Cyperus textilis & 0.000179 \\
\hline Cyperus textilis & 0.000000422 & Cynodon dactylon & 0.000216 \\
\hline Phragmites australis & 0.000000530 & Phragmites australis & 0.00025 \\
\hline Typha capensis & 0.000000935 & Juncus lomatophyllus & 0.000915 \\
\hline Isolepsis prolifera & 0.0000203 & Isolepsis prolifera & 0.00103 \\
\hline Zantedeschia aethiopica & 0.0000266 & Eleocharis limosa & 0.00115 \\
\hline Juncus effuses & 0.0000951 & Typha capensis & 0.00118 \\
\hline Juncus kraussii & 0.000304 & Juncus effuses & 0.00133 \\
\hline Aristea capitata & 0.000461 & Zantedeschia aethiopica & 0.0014 \\
\hline Bolboschoenus maritimus & 0.00242 & Aristea capitate & 0.00287 \\
\hline Juncus lomatophyllus & 0.00317 & Juncus kraussii & 0.0066 \\
\hline Eleocharis limosa & 0.00613 & Bolboschoenus maritimus & 0.022 \\
\hline *Arctotis acaulis & 0.0627 & Carpobrotus edulis & 0.151 \\
\hline Carpobrotus edulis & 0.0687 & Arctotis acaulis & 0.234 \\
\hline SRP & & 225 mg/L glyphosate & \\
\hline Cyperus textilis & 0.000000886 & Bolboschoenus maritimus & 0.0242 \\
\hline Cynodon dactylon & 0.00000129 & Aristea capitate & 0.0258 \\
\hline Phragmites australis & 0.00000153 & Typha capensis & 0.0266 \\
\hline Juncus lomatophyllus & 0.0000183 & Juncus effuses & 0.0284 \\
\hline Typha capensis & 0.0000421 & Isolepsis prolifera & 0.0284 \\
\hline Eleocharis limosa & 0.0000495 & Cyperus textilis & 0.0346 \\
\hline Juncus effuses & 0.0000831 & Eleocharis limosa & 0.043 \\
\hline Bolboschoenus maritimus & 0.000346 & Phragmites australis & 0.046 \\
\hline Juncus kraussii & 0.00127 & Arctotis acaulis & 0.048 \\
\hline Zantedeschia aethiopica & 0.00129 & Zantedeschia aethiopica & 0.0656 \\
\hline Isolepsis prolifera & 0.00196 & Carpobrotus edulis & 0.0892 \\
\hline Aristea capitata & 0.0304 & Juncus kraussii & 0.13 \\
\hline Carpobrotus edulis & 0.038 & Juncus lomatophyllus & 0.145 \\
\hline Arctotis acaulis & 0.142 & Cynodon dactylon & 0.254 \\
\hline
\end{tabular}

$\mathrm{n}=4$, each species is represented by 2 plant silos per pollutant treatment

${ }^{*}$ Grey shaded $=$ removal not significantly different compared to the unvegetated soil

glyphosate-based herbicide was excluded from the $t$-test due to limited data points available for statistical evaluation, due to a lack of replicates. The results of the $t$-test of means for two independent sample scores are illustrated in Table 6. The $p$-values indicate significant differences between the majority of indigenous species found within Renosterveld and the unvegetated soil control.

From Table 6, the difference in pollutant removal efficiency between plant species and unvegetated soil was more prevalent for the removal of fertiliser nutrients, than herbicides. The 


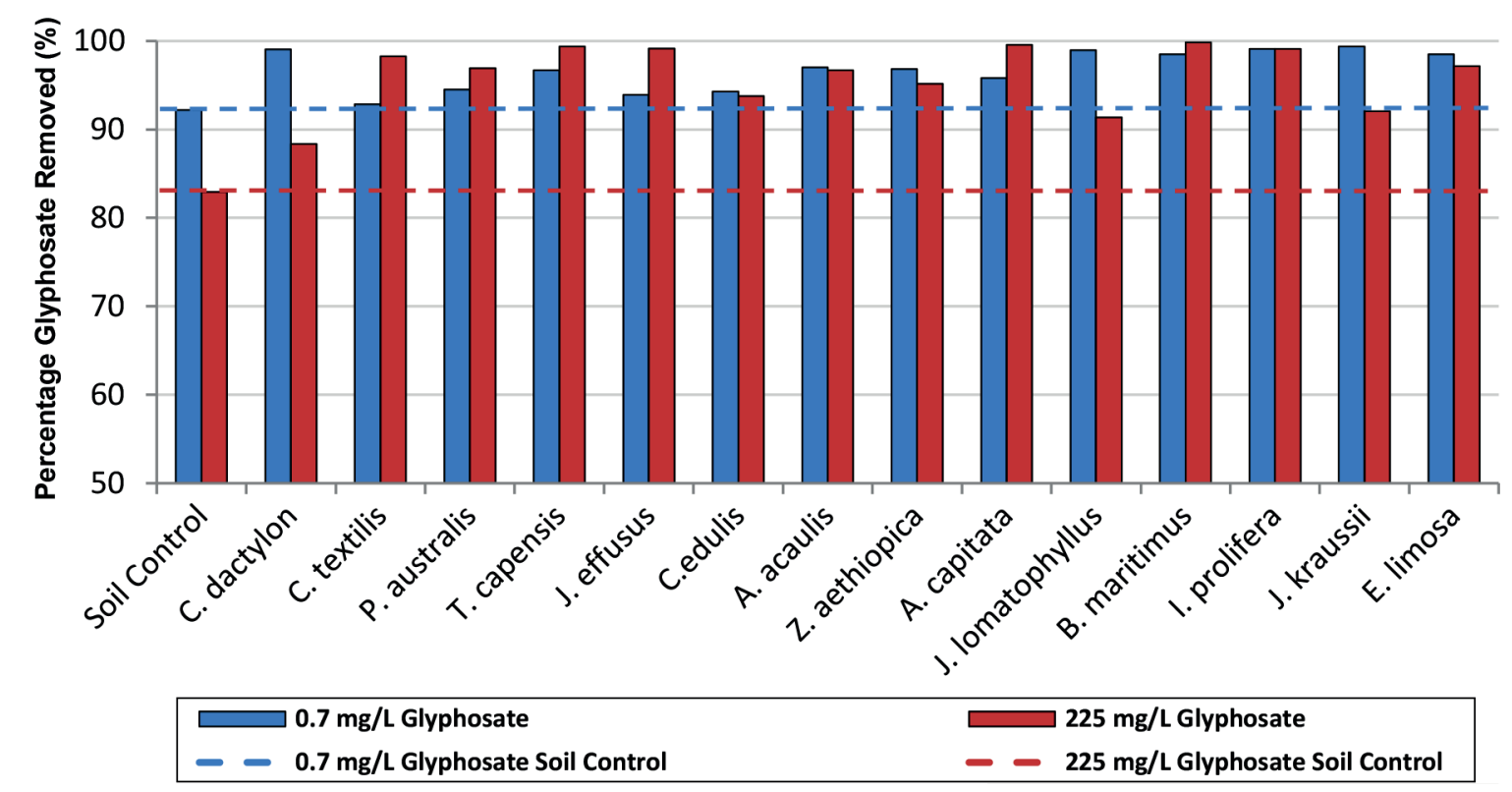

Figure 4. Average herbicide pollutant removal of individual plant species and soil

dissimilarity in fertiliser nutrient removal performance between vegetation and unvegetated soil is evident in the $p$-values. In contrast, vegetation did not display significant variation between species for the removal of glyphosate. Similar glyphosate removal is evident when comparing the plant species and the unvegetated soil. Glyphosate removal performance similarity is attributed to soil media's remediation capabilities, with majority removal occurring within the soil media.

Nutrient bioremediation may be attributed to a variety of processes that are potentially involved: phytotransformation, rhizosphere bioremediation, phytostabilisation, phytoextraction, phytovolatilization, phytostimulation and phytodegradation (Terry and Banuelos, 2000; Dietz and Schnoor, 2001; Pilon-Smits, 2005) Glyphosate remediation within the effluent solution, however, is largely attributed to adsorption to soil, microbial degradation occurring predominantly in soil, phytostabilisation, rhizosphere bioremediation, root binding, herbicide immobilization and a reduction in herbicide half-life as a result of plant interaction (Comes et al., 1976; Piccolo et al., 1992; Alvord and Kadlec, 1995; Chamberlain et al., 1996; Schuette, 1998; Terry and Banuelos, 2000; Dietz and Schnoor, 2001; Pilon-Smits, 2005; Cerdeira and Duke, 2006; Lipok et al., 2010; Pérez et al., 2011; Dosnon-Olette et al., 2011; Coupe et al., 2012; Beltrano et al., 2013; Gomes et al., 2016).

\section{Indigenous wetland plant species versus IAP and palmiet vegetation}

This objective evaluated and compared the removal efficiencies of indigenous wetland plant species displaying rapid transpiration and growth and IAP species currently used in SuDS, constructed wetlands and biofiltration treatment trains, in addition to palmiet. Plants of similar physiology were selected for community comparison.

As mentioned previously, the Renosterveld species selected for this test included: Phragmites australis, Cyperus textilis, Typha capensis and Cynodon dactylon. The IAP species were: Canna indica, Prionium serratum (included with IAPs due to its absence in the area under study and aggressive growth properties), Arundo donax and Pennisetum clandestinum. All selected pollutants and water quality parameters were analysed across 4 rounds of sampling $(n=4)$. The aim was to examine whether potential opportunity exists for the integration of the less invasive indigenous plant species instead of the IAP species currently used in local and international constructed wetlands, SuDS and biofiltration systems (Bratieres et al., 2008; Read et al., 2008; Schachtschneider et al., 2010; Milandri et al., 2012). Both the Renosterveld and IAP plus palmiet assemblages were more effective in the removal of pollutants than unvegetated soil. This finding is supported by a $t$-test, evaluating the relationship between the three media. The Student's $t$-test determined whether the removal efficiencies of two independent media are significantly different from each other.

From Table 7, the pollutant removal of both Renosterveld and IAP plus palmiet assemblages are significantly better than that of the unvegetated soil, indicating both vegetation types to be significantly more effective than unvegetated soil, across pollutants. The $p$-values generated by comparing Renosterveld and IAP plus palmiet assemblages indicate that the two vegetation types are very similar with regard to pollutant extraction and degradation.

It can thus be concluded that the pollutant removal performance of one vegetative assemblage is not significantly more effective than the other. This performance similarity between indigenous and alien assemblages supports the use of wetland species that naturally occur within Renosterveld, instead of their more invasive alien counterparts, in remediation treatment technologies.

Table 7. Comparison of pollutant removal performance between biofilter media

\begin{tabular}{|c|c|c|c|c|}
\hline \multirow{2}{*}{$\begin{array}{l}\text { Comparison } \\
\text { (t-test) of removal } \\
\text { performance per } \\
\text { biofilter type }\end{array}$} & \multicolumn{4}{|c|}{ Pollutant } \\
\hline & $\mathrm{NH}_{3}-\mathrm{N}$ & $\mathrm{NO}_{3}^{-}-\mathrm{N}$ & SRP & $\begin{array}{c}225 \mathrm{mg} / \mathrm{L} \\
\text { Glyphosate }\end{array}$ \\
\hline $\begin{array}{l}\text { Renosterveld } \\
\text { versus soil ( } p \text {-value) }\end{array}$ & 0.000523 & 0.00394 & 0.0136 & 0.00829 \\
\hline $\begin{array}{l}\text { IAP plus palmiet } \\
\text { versus soil ( } p \text {-value) }\end{array}$ & 0.00147 & 0.00282 & 0.0031 & 0.00495 \\
\hline $\begin{array}{l}\text { Renosterveld } \\
\text { versus IAP plus } \\
\text { palmiet ( } p \text {-value) }\end{array}$ & * 0.233 & 0.463 & 0.216 & 0.135 \\
\hline
\end{tabular}




\section{Ranked community performance effective across all pollutants}

In determining potential indigenous wetland species efficient in phytoremediation systems, we evaluated the remediation performance values of individual species across agricultural pollutants, with notable values benefitting the establishment of effective biodiverse plant assemblages, supporting heterogeneity. The percentage pollutant remediation efficiency per species for the duration of the experiment was taken into consideration, with a rank order established. The individual phytoremediatory capabilities of the plant species were used to identify an assemblage of plants capable of targeting pollutants from agricultural runoff.

In analysing the mean percentage pollutant removal of each species across all pollutants, individual species' remediation performance is given (Table 8). The percentage removal values obtained indicate to what extent the plant species differ with regard to their individual agricultural pollutant removal.

From Table 8, it is evident that the three most effective species - Cyperus textilis, Phragmites australis and Cynodon dactylon - displayed substantially greater percentage pollutant removal efficiencies compared to the unvegetated soil control. The findings further illustrate that the removal efficiency of all plant species was greater than the unvegetated soil control, across the agricultural pollutants analysed within this study. All wetland plant species showed significant pollutant removal averaged across all pollutants, compared to unvegetated soil. We can conclude that all indigenous wetland plant species were significantly more effective than unvegetated soil for the remediation of agricultural nutrients and herbicides.

\section{CONCLUSIONS}

Investigating the remediation performance between indigenous wetland species found in Renosterveld and unvegetated soil indicated that all indigenous plant species displayed greater pollutant removal than soil alone. However, soil media contributed to the pollutant removal efficiencies of vegetation and in all cases remediated the pollutants to an extent. It is important to acknowledge that vegetation consistently exceeded the removal efficiencies of unvegetated soil media. All plant species were effective in removing the fertiliser nutrients $\left(\mathrm{NH}_{3}\right.$, $\mathrm{NO}_{3}^{-}$and $\mathrm{PO}_{4}{ }^{3-}$ ). The species displaying the greatest percentage fertiliser removal were Cynodon dactylon, Phragmites australis and Cyperus textilis. Removal of the glyphosate-based herbicide pollutants across all species was greater than $92.84 \%$, with soil media contributing substantially (92.21\%), depicting Juncus kraussii, Isolepsis prolifera and Cynodon dactylon as the most prominent species for the removal of $0.7 \mathrm{mg} / \mathrm{L}$ glyphosate and Bolboschoenus maritimus, Aristea capitata and Typha capensis as the most effective species in the removal of $225 \mathrm{mg} / \mathrm{L}$ glyphosate.

The indigenous plant assemblage (Phragmites australis, Cyperus textilis, Typha capensis and Cynodon dactylon) was found to exhibit equivalent removal efficiencies across all agricultural pollutants when compared to the three IAP species (Canna indica, Arundo donax and Pennisetum clandestinum) and Prionium serratum, with both assemblages displaying effective phytoremediation. Both assemblages additionally displayed better remediation than the unvegetated soil control. At locations subjected to high agricultural and urban pollution, resulting in the degradation of endangered indigenous vegetation, there is a need to treat pollutants responsibly (Schachtschneider et al., 2010). Phytoremediation is a popular technology of choice, due to its cost-effectiveness, aesthetic advantages and longterm applicability. The indigenous versus IAP plus palmiet
Table 8. Ranked biofilter performance by percentage pollutant removal across all pollutants through time

\begin{tabular}{|c|c|c|c|}
\hline Rank & Biofilter type & $\begin{array}{l}\text { Pollutants } \\
\text { removed (\%) }\end{array}$ & $\begin{array}{c}\text { Comparison of } \\
\text { performance with soil } \\
\text { control ( } p \text {-value) }\end{array}$ \\
\hline 1 & Cyperus textilis & 96.42 & 0.00000000217 \\
\hline 2 & Phragmites australis & 95.89 & 0.00000000113 \\
\hline 3 & Cynodon dactylon & 95.08 & 0.0000000105 \\
\hline 4 & Typha capensis & 94.22 & 0.000000584 \\
\hline 5 & Juncus effuses & 92.82 & 0.0000088 \\
\hline 6 & Eleocharis limosa & 92.54 & 0.0000642 \\
\hline 7 & Isolepsis prolifera & 92.24 & 0.0000337 \\
\hline 8 & $\begin{array}{l}\text { Bolboschoenus } \\
\text { maritimus }\end{array}$ & 91.47 & 0.000742 \\
\hline 9 & Juncus kraussii & 90.89 & 0.0000116 \\
\hline 10 & Juncus lomatophyllus & 90.67 & 0.000000148 \\
\hline 11 & Aristea capitate & 90.08 & 0.000115 \\
\hline 12 & Zantedeschia aethiopica & 88.99 & 0.00000193 \\
\hline 13 & Arctotis acaulis & 78.94 & 0.0474 \\
\hline 14 & Carpobrotus edulis & 78.21 & 0.00751 \\
\hline 15 & Soil control & 72.03 & \\
\hline
\end{tabular}

$\mathrm{n}=4, d f=3$.

assemblages findings suggest that the invasive alien plants can be substituted with the less invasive indigenous plant species, in this case Renosterveld, without losing remediation performance. This, in turn, could contribute to the conservation of endangered vegetation, by increasing the natural biodiversity of an ecoregion.

In ranking the combined pollutant removal efficacy per species (nutrient and herbicide removal) the study identified plants that exhibit significant remediation of contaminated soil-water across all agricultural pollutants compared to soil only. The combined mean percentage pollutant removal of indigenous species for the duration of the study ranged from $78.3-96.24 \%$ (average combined pollutant removal 90.63\%), with the soil control removing, on average, $71.82 \%$. These removal efficiencies are comparable to the findings of similar local and international studies that focused on the biofiltration of stormwater and mineleachate using wetland plants (Bratieres et al., 2008; Read et al., 2008; Milandri et al., 2012).

\section{Use of wetland plant species for phytoremediation in Renosterveld}

Various factors influence the capacity of riparian buffers to remove agricultural pollutants from surface water-runoff and groundwater, in turn influencing nutrient and herbicide availability for extraction. The location, topography, adjacent agricultural practice, plant choice (biodiversity), pollutants and orientation of extant Renosterveld fragments all contribute to the successful implementation of conservation corridors capable of phytoremediation. For instance, not only must plants survive the local climatic conditions and varying agricultural pollutant products, but pollutant retention varies between plant species. The phytoremediatory role of Renosterveld vegetation in conservation corridors can provide a holistic approach to conserving the already fragmented landscape.

The species utilized within this study displayed majority removal across all pollutants, making them attractive options for inclusion in vegetative buffer strips in river corridors. The use of both dryland and wetland plant species in this study allows for the design of biodiverse vegetative buffer strips, with plant species selected capable of thriving at various distances from aquatic freshwater systems and along the slope of a riverbank. 
Indigenous species which exhibit poor remediation capabilities may contribute to buffer strips by potentially hindering flow rates, and stabilising sedimentation. By reducing the runoff rate and transport of sediments, pollutant infiltration into the soil is encouraged, with the rhizosphere the most active location for pollutant extraction. Vegetative buffers in river corridors adjacent to cultivated land extract $\mathrm{N}$ and $\mathrm{P}$ from agricultural fertiliser runoff prior to pollutant deposition into watercourses. This improves the water quality, restraining cyanobacterial bloom establishment, the result of rapid $\mathrm{N}$ and $P$ accumulation in freshwater systems, with eutrophication and salinisation processes regulated. Plant species implemented in ecological infrastructure have alternative traditional and contemporary uses, in food and drink, health and beauty, and skills and crafts (Van Wyk and Gericke, 2000). Various species used in this study have been identified for alternative uses, which include Carpobrotus edulis, Cyperus textilis, Typha capensis, Zantedeschia aethiopica, Phragmites australis and Juncus kraussii as sources of food and medicine (De Vynck et al., 2016). Additionally, many are popularly used in trinkets, crafts, thatching and fuel for burning (Cunningham, 2001).

Incorporating indigenous plant species, both excellent and poor phytoremediators of agricultural pollutants, creates a mutualistic relationship. The vegetation hinders surface and subsurface flow rates, where $\mathrm{N}$ and $\mathrm{P}$ are extracted, translocated, metabolised or volatised by plants. The pollutants in the soil and water bind to the roots and cell walls, hemicellulose within the cell, and are transported to different parts of the plant. For the remediation of herbicides, mechanisms include: adsorption to soil, microbial degradation occurring predominantly in soil, phytostabilisation, rhizosphere bioremediation, root binding, immobilisation and a reduction in herbicide half-life as a result of plant interaction.

Habitat connectivity is essential in maintaining natural ecosystems, whereas transformation triggered by habitat fragmentation exhibits detrimental effects to heterogeneity. Although fragmented, the areas directly contribute to the sustainability of the landscape. Indigenous plant species found in Renosterveld contribute to the biodiversity of the fragmented landscape, aiding conservation of this critically endangered vegetation type. The establishment of conservation corridors as a result of their purification potential would link the islands of Renosterveld fragments.

This study did not investigate the phytoremediatory performance of the species in drought conditions, due to the lack of agricultural pollutant transportation due to negligible surface runoff from agricultural farmlands during dry periods.

\section{ACKNOWLEDGEMENTS}

This research was funded by The Rufford Foundation (UK), with project identity: [23296-1].

\section{REFERENCES}

ALVORD HH and KADLEC RH (1995) The interaction of atrazine with wetland sorbents. Ecol. Eng. 5 (4) 469-479. https://doi. org/10.1016/0925-8574(95)00036-4

ANDERSON TA, GUTHRIE EA and WALTON BT (1993) Bioremediation in the rhizosphere. Environ. Sci. Technol. 27 (13) 2630-2636. https://doi.org/10.1021/es00049a001

ARUMI JL, OYARZÚN R and SANDOVAL M (2005) Natural protection against groundwater pollution by nitrates in the Central Valley of Chile. Hydrol. Sci. J. 50 (2). https://doi.org/10.1623/ hysj.50.2.331.61799

BARCELO D (1997) Trace Determination of Pesticides and their Degradation Products in Water. Elsevier, Amsterdam.
BEACH ED and CARLSON GA (1993) A hedonic analysis of herbicides: do user safety and water quality matter? Am. J. Agric. Econ. 75 (3) 612-623. https://doi.org/10.2307/1243568

BELTRANO J, RUSCITTI M, ARANGO C and RONCO M (2013) Changes in the accumulation of shikimic acid in mycorrhized Capsicum annuum L. grown with application of glyphosate and phosphorus. Theor. Exp. Plant Physiol. 25 (2) 125-136. https://doi. org/10.1590/S2197-00252013000200005

BRATIERES K, FLETCHER TD, DELETIC A and ZINGER Y (2008) Nutrient and sediment removal by stormwater biofilters: A largescale design optimisation study. Water Res. 42 (14) 3930-3940. https://doi.org/10.1016/j.watres.2008.06.009

BUDD R, O'GEEN A, GOH KS, BONDARENKO $S$ and GAN J (2009) Efficacy of constructed wetlands in pesticide removal from tailwaters in the Central Valley, California. Environ. Sci. Technol. 43 (8) 2925-2930. https://doi.org/10.1021/es802958q

BUOL SW, SOUTHARD RJ, GRAHAM RC and MACDANIEL PA (2011). Soil Genesis and Classification. John Wiley and Sons Inc, Iowa. https://doi.org/10.1002/9780470960622

CERDEIRA AL and DUKE SO (2006). The current status and environmental impacts of glyphosate-resistant crops. J. Environ. Qual. 35 (5) 1633. https://doi.org/10.2134/jeq2005.0378

CHAMBERLAIN K, EVANS AA and BROMILOW RH (1996). 1-Octanol/water partition coefficient (Kow) and $\mathrm{pKa}$ for ionisable pesticides measured by a $\mathrm{pH}$-metric method. Pesticide Sci. 47 (3) 265-271. https://doi.org/10.1002/ (SICI)1096-9063(199607)47:3<265::AID-PS416>3.0.CO;2-F

CHËVRE N, LOEPFE C, SINGER H, STAMM C, FENNER K and ESCHER BI (2006). Including mixtures in the determination of water quality criteria for herbicides in surface water. Environ. Sci. Technol. 40 (2) 426-435. https://doi.org/10.1021/es0502391

COMES RD, BRUNS VF and KELLEY AD (1976). Residues and persistence of glyphosate in irrigation water. Weed Sci. 24 (1) 47-50. https://doi.org/10.1017/S0043174500065395

CONSTANTINE M, MUSINGAFI C and TOM T (2014). Fresh water sources pollution: a human related threat to fresh water security in South Africa. Res. Acad. Soc. Sci. 1 (2) 72-81.

COUPE R, KALKHOFF S, CAPEL P and GREGOIRE C (2012) Factors affecting the fate and transport of glyphosate and AMPA into surface waters of agricultural watersheds in the United States and Europe. EGU General Assembly Conference Abstracts 145877.

CUNNINGHAM A (2001) Applied Ethnobotany. Routledge, London.

CURTIS O (2013) Management of critically endangered Renosterveld fragments in the Overberg, South Africa. PhD thesis, University of Cape Town.

DABROWSKI JM (2001) Prediction and ecotoxicological effects of runoff induced pesticide contamination in agricultural surface waters: a risk assessment using GIS and microcosms. PhD thesis, Stellenbosch University.

DAFF (Department of Agriculture, Forestry and Fisheries, South Africa) (2016) Production guideline for canola. Sun Media, Stellenbosch.

DE KOCK (2017) Personal communication, 08 March 2017. Mr Ewald de Kock, ProtekSA, Gauteng Province, South Africa, 2032.

DE VILLIERS S and THIART C (2007) The nutrient status of South African rivers: Concentrations, trends and fluxes from the 1970s to 2005. S. Afr. J. Sci. 103 (7-8) 343-349.

DE VYNCK JC, VAN WYK BE and COWLING RM (2016) Indigenous edible plant use by contemporary Khoe-San descendants of South Africa's Cape South Coast. S. Afr. J. Bot. 102 60-69. https://doi. org/10.1016/j.sajb.2015.09.002

DIETZ AC and SCHNOOR JL (2001) Advances in phytoremediation. Environ. Health Perspect. 109 (1) 163-168. https://doi.org/10.1289/ ehp.01109s1163

DOSNON-OLETTE R, COUDERCHET M, OTURAN MA, OTURAN $\mathrm{N}$ and EULLAFFROY P (2011) Potential use of Lemna minor for the phytoremediation of isoproturon and glyphosate. Int. J. Phytoremed. 13 (6) 601-612. https://doi.org/10.1080/15226514.2010.525549

GILIOMEE JH (2006) Conserving and increasing biodiversity in the large-scale, intensive farming systems of the Western Cape, South Africa. S. Afr. J. Sci. 102 9-10.

GOMES MP, LE MANAC'H SG, MOINGT M, SMEDBOL E, PAQUET S, LABRECQUE M, LUCOTTE M and JUNEAU P (2016) Impact of phosphate on glyphosate uptake and toxicity in willow. J. Hazardous 
Mater. 304 269-279. https://doi.org/10.1016/j.jhazmat.2015.10.043

HENZE M (2008) Biological Wastewater Treatment: Principles, Modelling and Design. IWA Publishers, London.

HUGHES JB, SHANKS J, VANDERFORD M, LAURITZEN J and BHADRA R (1997) Transformation of TNT by aquatic plants and plant tissue cultures. Environ. Sci. Technol. 31 (1). https://doi. org/10.1021/es960409h

KANWAR RS, COLVIN TS and KARLEN DL (1997) Ridge, moldboard, chisel, and no-till effects on tile water quality beneath two cropping systems. J. Prod. Agric. 10 (2) 227-234. https://doi.org/10.2134/ jpa1997.0227

KEMPERJ, COWLING RMand RICHARDSONDM (1999) Fragmentation of South African Renosterveld shrublands: Effects on plant community structure and conservation implications. Biol. Conserv. 90 (2) 103-111. https://doi.org/10.1016/S0006-3207(99)00021-X

KING KW, BALOGH JC, AGRAWAL SG, TRITABAUGH CJ and RYAN JA (2012) Phosphorus concentration and loading reductions following changes in fertilizer application and formulation on managed turf. J. Environ. Monit. 14 (11) 2929. https://doi.org/10.1039/ c2em30213f

LAM QD, SCHMALZ B and FOHRER N (2010) Modelling point and diffuse source pollution of nitrate in a rural lowland catchment using the SWAT model. Agric. Water Manage. 97 (2) 317-325. https://doi. org/10.1016/j.agwat.2009.10.004

LEE GF, RAST W and JONES RA (1978) Water Report: Eutrophication of water bodies: Insights for an age old problem. Environ. Sci. Technol. 12 (8) 900-908. https://doi.org/10.1021/es60144a606

LIPOK J, STUDNIK H and GRUYAERT S (2010) The toxicity of Roundup 360 SL formulation and its main constituents: Glyphosate and isopropylamine towards non-target water photoautotrophs. Ecotoxicol. Environ. Saf. 73 (7) 1681-1688. https://doi.org/10.1016/j. ecoenv.2010.08.017

LOWRANCE R, LEONARD R and SHERIDAN J (1985) Managing riparian ecosystems to control nonpoint pollution. J. Soil Water Conserv. 40 (1) 87-91.

MARA D (2004) Domestic Wastewater Treatment in Developing Countries. Earthscan, London.

MCDOWELL C and MOLL E (1992) The influence of agriculture on the decline of west coast Renosterveld, south-western Cape, South Africa. J. Environ. Manage. 35 (3) 173-192. https://doi.org/10.1016/ S0301-4797(05)80118-5

MENSAH PK, PALMER CG and MULLER WJ (2013) Derivation of South African water quality guidelines for Roundup ${ }^{\circ}$ using species sensitivity distribution. Ecotoxicol. Environ. Saf. 96 24-31. https:// doi.org/10.1016/j.ecoenv.2013.06.009

MILANDRI SG, WINTER KJ, CHIMPHANGO SBM, ARMITAGE NP, MBUI DN, JACKSON GE and LIEBAU V (2012) The performance of plant species in removing nutrients from stormwater in biofiltration systems in Cape Town. Water SA 38 (5) 275-662. https://doi. org/10.4314/wsa.v38i5.2

PÉREZ GL, VERA MS and MIRANDA LA (2011) Effects of herbicide glyphosate and glyphosate-based formulations on aquatic ecosystems. Herbicides Environ. 343-368.

PICCOLO A, CELANO G and PIETRAMELLARA G (1992) Adsorption of the herbicide glyphosate on a metal-humic acid complex. Sci. Total Environ. 123 77-82. https://doi.org/10.1016/0048-9697(92)90134-E

PILON-SMITS E (2005). Phytoremediation. Annu. Rev. Plant Biol. 56 15-39. https://doi.org/10.1146/annurev.arplant.56.032604.144214

READ J, WEVILL T, FLETCHER T and DELETIC A (2008) Variation among plant species in pollutant removal from stormwater in biofiltration systems. Water Res. 42 (4-5) 893-902.

READ J, FLETCHER TD, WEVILL T and DELETIC A (2010) Plant traits that enhance pollutant removal from stormwater in biofiltration systems. Int. J. Phytoremed. 12 (1) 34-53. https://doi.org/10.1016/j. watres.2007.08.036

REDFIELD AC (1958) The biological control of chemical factors in the environment. Am. Sci. 46 (3) 230A-221.

ROUGET M, RICHARDSON DM and COWLING RM (2003) The current configuration of protected areas in the Cape Floristic Region, South Africa - Reservation bias and representation of biodiversity patterns and processes. Biol. Conserv. 112 (1-2) 129-145. https://doi. org/10.1016/S0006-3207(02)00396-8

SANBI (2003) Cape Lowlands Renosterveld Project. URL: http://bgis. sanbi.org/Projects/Detail/163 (Accessed 22 December 2017).

SCHACHTSCHNEIDER K, MUASYA M and SOMERSET V (2010) Are indigenous sedges useful for phytoremediation and wetland rehabilitation? Report no CSIR NE04-PO. CSIR,, Pretoria.

SCHNOOR JL, LICHT LA, MCCUTCHEON SC, WOLFE NL and CARREIRA LH (1995) Phytoremediation of organic and nutrient contaminants: Pilot and full-scale studies are demonstrating the promise and limitations of using vegetation for remediating hazardous wastes in soils and sediments. Environ. Sci. Technol. 29 (7) 318-323. https://doi.org/10.1021/es00007a747

SCHOUMANS OF, CHARDON WJ, BECHMANN ME, GASCUELODOUX C, HOFMAN G, KRONVANG B, RUBAEK GH, ULÉN B and DORIOZ JM (2014) Mitigation options to reduce phosphorus losses from the agricultural sector and improve surface water quality: A review. Sci. Total Environ. 468 1255-1266. https://doi. org/10.1016/j.scitotenv.2013.08.061

SCHUETTE J (1998) Environmental fate of glyphosate. Environ. Monit. Pest Manage. 1 (1) 1-13.

SEKABIERA K, ORYEM-ORIGA H, MUTUMBA G, KAKUDIDI E and BASAMBA TA (2011) Heavy metal phytoremediation by Commelina benghalensis (L) and Cynodon dactylon (L) growing in urban stream sediments. Int. J. Plant Physiol. Biochem. 3 (8) 133-142.

TERRY N and BANUELOS GS (2000) Phytoremediation of Contaminated Soil and Water. Ringgold Inc., Portland. https://doi. org/10.1201/9781439822654

TRAN N, DROGUI P, DOAN TL, LE TS and NGUYEN HC (2017) Electrochemical degradation and mineralization of glyphosate herbicide. Environ. Technol. 38 (23) 2939-2948. https://doi.org/10.10 $80 / 09593330.2017 .1284268$

VAN WYK BE and GERICKE N (2000) People's Plants: A Guide to Useful Plants of Southern Africa. Briza Publications, Pretoria. 351 pp.

VON HASE A, ROUGET M, MAZE K and HELME N (2003) A finescale conservation plan for Cape lowlands Renosterveld: technical report. Report no CCU 2/03. Cape Conservation Unit, Botanical Society of South Africa, Claremont.

YOU J, KALJURAND $M$ and KOROPCHAK JA (2003) Direct determination of glyphosate in environmental waters using capillary electrophoresis with electrospray condensation nucleation light scattering detection. Int. J. Environ. Anal. Chem. 83 (9) $797-$ 806. https://doi.org/10.1080/0306731031000111698

ZALIDIS G, STAMATIADIS S, TAKAVAKOGLOU V, ESKRIDGE K and MISOPOLINOS N (2002) Impacts of agricultural practices on soil and water quality in the Mediterranean region and proposed assessment methodology. Agric. Ecosyst. Environ. 88 (2) 137-146. https://doi.org/10.1016/S0167-8809(01)00249-3 